\title{
Lumen
}

Selected Proceedings from the Canadian Society for Eighteenth-Century Studies

\section{Hume and Historical Distance}

\section{Mark Salber Phillips}

Volume 21, 2002

URI : https://id.erudit.org/iderudit/1012265ar

DOI : https://doi.org/10.7202/1012265ar

Aller au sommaire du numéro

Éditeur(s)

Canadian Society for Eighteenth-Century Studies / Société canadienne d'étude du dix-huitième siècle

ISSN

1209-3696 (imprimé)

1927-8284 (numérique)

Découvrir la revue

Citer cet article

Phillips, M. S. (2002). Hume and Historical Distance. Lumen, 21, 1-19.

https://doi.org/10.7202/1012265ar

Copyright (c) Canadian Society for Eighteenth-Century Studies / Société canadienne d'étude du dix-huitième siècle, 2002
Ce document est protégé par la loi sur le droit d'auteur. L'utilisation des services d'Érudit (y compris la reproduction) est assujettie à sa politique d'utilisation que vous pouvez consulter en ligne.

https://apropos.erudit.org/fr/usagers/politique-dutilisation/ 


\section{Hume and Historical Distance}

Let me start by recollecting my first encounter with the question of distance in the expanded sense I want to give it. It came in the course of presenting an earlier study of mine to a group of undergraduates. The book concerns a $15^{\text {th }}$-century Florentine merchant and historian who played a small part in an attempt to displace the Medici regime. ${ }^{1}$ More an observer than an actor, the protagonist was admittedly a minor figure, but he offered me the opportunity to write a microhistory that would explore intersections of citizenship and historical consciousness in Quattrocento Florence. Teaching one's own work can be an embarrassing business, but I thought I was prepared to defend my choice. For one of my students, however, my solemn explanations about the value of understanding the historical world of an ordinary citizen seemed to carry little weight - certainly not enough to justify even the paperback price. 'Aren't you really saying,' he asked, 'that your generation came too late to write the really important stuff - the lives of people like Cosimo de' Medici or Lorenzo the Magnificent - so all that was left were the small potatoes, the little guys like Parenti?'

As sometimes happens to us all, my reply on this occasion came from an unexpected direction. 'I can see your point,' I said, 'but let me ask all of you a question. Let's say I have two books here on the battle of Stalingrad. One is an overall tactical account of this crucial battle. It looks at events from the point of view of the general staff and it details the success of the Soviet command in outmanoeuvering the German army, so that they were encircled, cut off from all supplies, and starved into surrendering. The other book takes a very different point of view. It depicts the ordinary German soldier's experience by using the letters captured by the Soviets when they closed the pincer on the German troops. These are anguished letters written by men facing starvation and defeat in the depths of a Russian winter."Which of these two books,' I

1 The Memoir of Marco Parenti (Princeton: Princeton UP, 1987; repr. Broadview 2000). 
asked the class, 'do you want to read?' The answer, as I expected, overwhelmingly favored the second, though one student astutely argued that there was no need to make a final choice. My point, I explained, was that the answer they gave should not be considered either right nor wrong, but it should certainly be taken seriously as an indication of contemporary sensibilities. Their preference for a close-up study, I argued, indicates a kind of knowledge our society finds especially attractive. We seem especially drawn to ordinary lives and intimate experience. The evidence is there in our journalism, our museum displays, and in our historical monuments. (Even our war memorials are not to generals or heroes, but to the unknown soldier.) The best conclusion, I argued, was not to disown the preference or to moralize about it; rather, the need is to understand it as a cultural choice and to think about its implications.

These and similar occasions have made me think that there are important issues to explore regarding the construction of historical distance. I emphasize the idea of a constructed distance because I am trying to get hold of something which goes beyond the usual sense that the passage of time confers new perspectives on history. Rather, what I have in mind is both more active and more general, since it addresses the ways in which every history works to position its audience in relation to the past. Distance in this expanded sense is something the reader experiences as well as the historian. It also takes in all points along a gradient of distances, including proximity or immediacy as well as remoteness or detachment. (We have no trouble recognizing that both the bungalow and the skyscraper have height; equally, we can say that every representation of the past manipulates distance, however foreshortened or extended.) By the same token, distance as I want to develop the term refers not simply to matters of form or genre, but to other significant dimensions of engagement or disengagement. Questions about distance should, therefore, direct themselves to a history's ideological impact as well as its emotional force, its cognitive assumptions as well as its aesthetic traits.

If every history, as I have suggested, must position its readers in some relationship of proximity or detachment to the past it describes, the issue of distance is as relevant to the long history of historical writing as it is to current practice. Thus, if the questions I have sketched about detachment or distance apply to the analytic programs and generalizing habits of Eric Hobsbawm or Ernest Gellner, they may be no less useful in reading the works of David Hume or Henry Thomas Buckle. Equally, if contemporary readers are attracted to the intriguing microhistories of Carlo Ginzburg or to the literary vivacity of Simon Schama, surely the same can be said for other audiences and other ages. Romantic narratives 
will quickly come to mind - Carlyle's Past and Present, for instance, or Michelet's Le Peuple - but we might also think of works in the chronicling tradition, like Dino Compagni's powerful eye witness account of Florentine politics in the time of Dante, or perhaps that most influential work of English historiography, Foxe's Acts and Monuments.

These last examples point to the fact that the questions of presence and distance I am raising are not confined to genres we now regard as canonically historiographical. Not only chronicle and martyrology, but also biography and memoir often carry with them a particular sense of immediacy, and the same is also true for local history, family history, and much literary history. By the same token, antiquarianism, universal history, or encyclopedic writing are generally presented in the impersonal tones of disinterested inquiry. Indeed, if we press the question, it is soon apparent that tacit assumptions about distantiation and proximity are a key element in the way in which we distinguish the various genres. The distinction between memoir and history, for example, or between microhistory and general history, surely depends upon the ability of audiences to recognize and accept assumptions of this kind.

So far I have focused on the writing of history, but there is no obvious reason to limit the discussion to textual representations. Though they employ a different vocabulary of forms, history painting, photography, documentary film, and museums all raise very similar questions. Indeed, museum displays, with their combination of concrete materials and a public setting, present some of the issues in their most tangible and accessible form. Few people, I would guess, outside of the academy could describe recent shifts in the direction of historical writing, but it takes no special museological awareness to spot large changes that have been taking place in museums. When faced with the varied displays of London's Imperial War Museum, for example, few visitors would have any difficulty in distinguishing the traditional mahogany and glass cases filled with swords and military uniforms from newer displays like 'The Trench Experience' or 'The Blitz Experience' where (as the titles indicate) we are invited to relive a specific moment or milieu from the past.

In most contemporary museums, curators and designers are exploring more participatory forms of display, replacing what are now regarded as the static and overly academic presentations prevalent in an earlier day. While stopping short of full-scale 'disneyfication,' they strive to animate their exhibitions in ways that will give the visitor a sense of the past that is socially more comprehensive and visually more immediate. The contemporary museum, in short, invites us to imagine the past as a field of experience, rather than as an object of study - a program 
that has evident parallels with some of those occuring in the more secluded world of professional historiography. In fact, the Imperial War Museum offers its visitors much the same historiographical choice I offered my students, and it operates on a similar conviction that the contemporary audience will gravitate towards those representations of war that are more democratic in their politics and more immediate in their emotional impact.

Several aspects of the problem emerge with particular clarity from the example of the museum, where choices about modes of representation, as I have said, take on a particularly public expression. First, the control of distance clearly involves much more than aesthetic or emotional impact alone. Inevitably, it also carries with it significant ideological implications. Speaking here in Toronto, the example that comes first to mind is Into the Heart of Africa at the Royal Ontario Museum. The show exhibited primitivist stereotypes of Africans in the service of what was intended as a critical look at the racist attitudes of nineteenth-century missionaries. For Toronto's Caribbean community, however, the images spoke louder - spoke more directly - than the words. They read the depictions of powerlessness and backwardness as degrading, whatever the text panels might say. In short, significant portions of the public could not (or would not) adopt the more distantiated perspective assumed by the curators.

Second, there is the issue of change itself. I am certainly not suggesting that every product of a particular historiographical moment will manifest a single, uniform stance of engagement or detachment. Nonetheless, the parallels I have noted between museum practice and historical writing suggest the idea that the representation of the past, taken in its widest sense, may indeed undergo significant shifts of perspective from time to time. If so, variation in assumptions about distance would not only be an important feature of the way in which readers distinguish the various historical genres (memoir, microhistory etc.), but shifts of this kind may also play a significant role in shaping the development of historiography.

The usefulness of raising questions of distance in relation to the evolution of historical thought will be easier to see if we are clearer about the various levels on which distance operates. The brief sketch I have given of the contemporary museum has suggested a number of important considerations, namely the formal vocabulary of display, its affective power, and its ideological implication. Beyond this, however, there remains a further dimension that we might call the cognitive, and this too can be an ingredient in change. It is a cliché, of course, that every generation makes its own history, but we normally take this to mean something relatively superficial. Old heroes will be found wanting, 
origins will be pushed further back, great events will be given a new political or social coloration. Yet, beyond any set of particulars, we also know that there is a point at which new forms of historical representation reflect altered conditions of explanation or understanding. At such moments, new criteria of significance or intelligibility emerge, with the result that history is not simply populated in different ways, but imagined in new terms.

On this level, changes of distance may be less frequent, but they are more profound, and they carry with them some clues to the evolution of historical thought in the longer term. In particular, attention to cognitive distance may be helpful in understanding how, as the grounds of representation shift, an historical style becomes dated and appears to lose its grip on the most serious issues. Renaissance humanism, for example, succeeded for a time in marginalizing much of the historiographical inheritance of Christian Europe. Chronicles lost prestige and their qualities of abundance and immediacy came to seem muddled in comparison to the dignity and linearity of the classical style. Equally, Enlightenment historians felt enormous confidence in their power to survey the historical landscape from a position of philosophical elevation, bringing not so much new information, but new schemas of explanation to their predecessors' narratives. But the explanatory schemes of one generation may seem little more than remote abstractions to another. Thus the Romantics condemned what they saw as the empty generalities of the Enlightenment histories and sought to endow their own narratives with renewed immediacy - only to be criticized in turn by the Positivist school, with its faith in evolutionary dogmas and its search for scientific regularities.

I do not want to give the impression that the history of historical thought can be reduced to a simple alternation between grand narratives and thick descriptions. Distance should not be treated as a single, undifferentiated quality with which we can tag a given text or a given school. Even within individual histories, let alone on the larger scale, distance remains a variable and complex effect, one shaped by balances or tensions between a variety of separable aspects of narrative construction and social or intellectual commitment. Nor, it should be emphasized, am I arguing for a fixed relationship between the various kinds of distances I have sketched. Indeed, it is worth the effort to separate the affective from the ideological, or the ideological from the cognitive precisely because each of these dimensions makes it own contribution to the reader's experience. Close-up description, for example, is often pursued as a way of enlisting the reader's sympathies in a political cause, as Edward Thompson explicitly does in 'seeking to rescue the poor stockinger, the Luddite cropper, the "obsolete" hand-loom weaver ... from 
the enormous condescension of posterity. ${ }^{2}$ Yet detailed narration is not always a strategy for creating sympathy, nor is immediacy in description always paired with ideological identification. Thus Michel Foucault's grisly description of the dismemberment of Damiens the regicide in the opening scene of Discipline and Punish is not calculated to make us identify with the criminal or to spur us to sympathy with efforts of penal reform; on the contrary, this horrific description is intended to shock us into abandoning our comfort with other, much more familiar regimes of punishment. In these terms, the graphic description of Damiens's death spectacle serves as a kind of Brechtian alienation-effect. It forces on us the necessary distance to recognize what is at stake in other forms of punishment, specifically in the new regime of surveillance instituted by the reforms of the Enlightenment.

\section{Distance in the Eighteenth-Century}

The idea of historical distance was not a matter of explicit discussion in the eighteenth century, any more than it has been in the twentieth, but there is a passage in Hume's essay 'Of Tragedy' that brings us very close to the topic. Hume writes that when Clarendon, the great historian of the English Revolution, approaches the execution of the king, he 'hurries over the king's death, without giving one circumstance of it.' Clarendon evidently

considers it as too horrid a scene to be contemplated with any satisfaction, or even without the utmost pain and aversion. He himself, as well as the readers of that age, were too deeply concerned in the events, and felt a pain from subjects, which an historian and a reader of another age would regard as the most pathetic and most interesting, and, by consequence, the most agreeable. ${ }^{3}$

Hume's subject in this essay is an old question in literary criticism: why tragedy pleases. In this context, his reference to history is almost

2 Edward Thompson, The Making of the English Working Class (Harmondsworth: Penguin, 1968) 12.

3 Hume, Essays, Moral, Political, and Literary, ed. Eugene Miller (Indianapolis: Liberty P, 1987) 223-24. In their edition of the Essays, Green and Grose identify this essay as having first appeared in Four Dissertaitions, published by Millar in 1757. 
incidental and certainly brief. Nonetheless, his sympathetic understanding of Clarendon's reticence, combined with his clear sense that the event that had been most painful to an earlier generation had become most 'interesting' to his own, points to an intriguing awareness of the variability of historical distance. In fact, despite the brevity of his remarks, Hume gives more than a hint of the many-sidedness of the subject.

First, there is the all-important issue of variability, which Hume puts at the centre of his discussion. He clearly accepts the fact that both Clarendon and his audience found themselves in a kind of proximity to the regicide that ruled out many potential representations of the event, especially (we surmise) the kind of detailed, pathetic treatment that Hume would offer his own readers in the History of England. The implication seems to be that variation in distance should not be considered a fault, but rather stands as a legitimate change in historical perspective. This sense is reinforced by the suggestion that the variation in distance may have little to do with the historian's individual preferences, being as much a property of the audience as of the writer

Second, Hume recognizes that distance must be considered both as a reflection of something occurring outside the text and a construction that operates within it to shape the emotional responses of the reader. Clearly, we can only understand the change in distance that separates Clarendon's sense of history from his own if we consider the difference in experience between their two generations. But if the passage of time had led to a new perception of events, the result was also to change the form and rhetoric of the narrative as much as its content. Clarendon's account was appropriate for its age, but no one now, Hume seems to say, could rest content with its hurried, uncircumstantial narrative. Rather, the contemporary reader, attracted by the pathos of the story, would be eager for a narrative that presented the royal tragedy in all its evocative detail.

Third, it seems important to note the literary context of Hume's discussion. In contrast to those essays that deal with issues of history, politics, or political economy, 'Of Tragedy' specifically addresses a tradition of belles-lettres. The question of tragedy's power to move the emotions goes back, of course, to Aristotle's discussion of catharsis in the Poetics, but Hume's real interlocutors in this essay are Dubos and Fontenelle, two key figures in French belletrist tradition. Thus Hume does not initially come to Clarendon's writing from an historiographical concern. Rather, he approaches the issue of historical distance from within a tradition of letters that had long been interested in literature's power to engage the emotions. The analogy of tragedy seems to have helped him to see a parallel issue in history, and to a large extent he 
simply extends an established question to a new genre ${ }^{4}$ - though in doing so he also expands the issue in important ways that are appropriate to the subject of history writing.

Finally, in keeping with the nature of his general subject, Hume puts his emphasis on the emotional impact of historical narrative, but at bottom the stakes are as much ideological as affective. If Clarendon's avoidance of this 'infinitely disagreeable' subject has an evident political meaning, so must the fact that a later reader could regard the same events as 'pathetic' and 'agreeable.' This layering of one kind of distance over another - formal, affective, and ideological - stands as a reminder not to think of distance as a single, unitary dimension. Rather, in exploring the theory and practice of historical writing in the eighteenth century, we need to be alert to the various kinds of distances I have spoken of and the variety of ways in which they may combine.

Looked at in this perspective, the problem of understanding eighteenth- century historiography becomes a matter of reconciling some very different postures in relation to the past - postures, it should be said, that often appear in the same author and indeed in the same text. On the one hand, there is a strong impulse in the Enlightenment to approach history as a kind of laboratory for establishing a naturalistic science of man. The result was a generalizing spirit that later generations came to deride, but which had inestimable importance at the time, since it underpinned the confidence of eighteenth-century historians that they held in their grasp principles of explanation that elevated their understanding beyond anything available to earlier writers. This was the spirit expressed by the Edinburgh clergyman and minor literary figure, John Logan, in a brief work entitled Elements of the Philosophy of History (1781): 'To common minds every thing appears particular,' wrote Logan, 'A Philosopher sees in the great, and observes a whole. The curious collect and describe. The scientific arrange and generalize. ${ }^{5}$

This side of Enlightenment historiography is well known; less so its other, more sentimental face. In fact, there is plenty of evidence that historians, much like contemporary novelists or poets, were keenly interested in engaging the reader's sympathies, especially by presenting scenes of virtue in distress. We may overlook this dimension of Enlight-

4 Fontenelle's solution to the problem - one which Hume largely accepts - is one that involves a kind of distantiation: 'We weep for the misfortune of a hero, to whom we are attached. In the same instant we comfort ourselves, by reflecting, that it is nothing but a fiction.' (Réflexions sur la poétique, as quoted by Hume, Essays, 218n.)

5 John Logan, Elements of the Philosophy of History (Edinburgh, 1781) 10. 
enment historiography if we focus on the more philosophical texts, but - following Hume's lead in the essay 'Of Tragedy' - we will find it strongly articulated in works on belles-lettres.

In short, raising the issue of distance leads us to recognize a split between two important features of the historical outlook of the eighteenth century. To simplify considerably, we can say that much of the most interesting historical work of the Enlightenment drew its strength from a theory of knowledge that assumed the importance of cognitive distance. Only the comprehensive philosophic eye, it was thought, could discern the underlying patterns that give order to the development of society. At the same time, if we turn our attention to matters of form, we have to recognize that the discussion of narrative in this period was strongly concerned with cultivating a sense of immediacy. History, they argued, no less than fiction, should exercise the moral imagination of its readers by presenting them with scenes that are as vivid and affecting as possible. This tension between cognitive distantiation and affective proximity becomes still more interesting when we recognize that many of the same voices speak prominently on both sides of this divide, perhaps most notably Lord Kames, Adam Smith, and David Hume himself.

One last introductory point: for those of us who read eighteenth-century histories with sympathy, the strain between these two impulses will seem an animating tension that adds life and interest to this literature. At the same time, recognizing this division also makes it easier to understand the way in which the work of this period fell out of favor with a subsequent generation of readers, who came to focus their attention selectively on only one side of the Enlightenment's historiographical legacy. In fact, the sentimentalism of Hume and his contemporaries contributed a great deal to the growing taste for immediacy in historical writing. In doing so, however, these writers unknowingly fostered a new climate of taste by which their own works would come to be judged as excessively cold and detached. The result was a second shift in distance, much like the one that Hume recognized as separating his own generation from that of Clarendon.

\section{Adam Smith's Lectures on Rhetoric}

I will come back to Hume shortly, since he presents us with a central example not simply of the tension I have spoken about but also of the way it could be resolved in a great historical narrative. But first I want to turn to Adam Smith whose early Lectures on Rhetoric present the period's most acute discussion of the problems of historical composition. 
Questions of distantiation and proximity enter into Smith's discussion of historiography at many levels. A good place to start may be with the distinction he draws between the historian and the orator. The difference, he argues, is founded in their different positions in relation both to their subject and their audience. 'The business of the one [i.e. the historian] is barely to narrate the facts which are often very distant from his time and in which he is, or ought to be and endeavours to appear, noways interested.' In contrast, the orator deals with subject that he or his friends 'are nearly concerned in.' As a result, whatever his real feelings, the orator's business is to appear 'deeply concerned in the matter' and he uses all of his skill to prove 'what he is engaged in. ${ }^{6}$

The result of this difference of 'circumstances' is a contrast of styles. The orator 'insists on every particular' and rehearses the facts from every point of view. 'What the historian would have said barely and in one sentence by this means is brought into a long series of different views of the same argument.' The orator will frequently exclaim on the justice of the cause, whereas the historian acts as if he were an impartial narrator of the facts. Accordingly, he 'uses none of these means to affect his readers, he never dwells on any circumstance, nor has he any use for insisting on arguments as he does not take part with either side ...'

Even though the starting point of Smith's discussion is novel, it seems headed towards a rather conventional picture of history as a genre marked by detachment and a high degree of decorum. In literary matters, Smith was, in fact, a convinced classicist, who disallowed any departure from the conventions of the classical historiographical tradition. Thus he not only frowned on historian's using any of the orator's rhetorical tricks, but he also forbade any admixture of the didactic style. Historical writing should consist of narration and narration alone. For this reason, he firmly opposed the introduction of learned and philosophical digressions into historical works, thus ruling out the innovations in historiographical form that Hume, Robertson and others would establish as the hallmark of Enlightenment philosophical history.

Smith's strict commitment to narrative, however, came with an equally strong interest in its sentimental proximities. In fact, much of the space he gives to historiography explores ways in which history can legitimately work to draw out the sympathies of the reader. Thus in a second passage on the difference between the historian and the orator,

6 Smith, Lectures on Rhetoric and Belles Lettres, ed. J. C. Bryce (Indianapolis: Liberty P, 1985) 35. For a fuller account of Smith's views of history, see my Society and Sentiment (Princeton UP, 2000), chapter 3. 
Smith acknowledges that both may 'excite our love or esteem for the persons he treats of,' but their means are different $(L R B L, 100)$. The orator can seem to be 'deeply affected with that affection he would have us feel,' while the historian 'can only excite our affection by the narration of the facts and setting them in as interesting a view as he possibly can.' Though a historian should not exclaim over his hero's life in the manner of the orator, he nonetheless 'may excite grief or compassion, but only by narrating facts which excite those feelings.' (LRBL, 101; emphasis added)

This is the crux of Smith's problem: how history can excite compassion without departing from narration. Smith's response is to produce a remarkable analysis of narrative technique that hinges on a distinction between direct and indirect description. Direct description describes the action as impartially observed, while indirect description gives us events as they are reflected in the responses of spectators. Smith vastly preferred the latter for its emotional power. No action, he observes, however 'affecting' it might be in itself, will be 'very interesting' when it is simply narrated in the direct manner. Such a description, he says, is generally 'languid and uninterresting in comparison of the other Sort where the effects of the transaction as well on the actors as the Spectators are pointed out.' $(L R B L, 86)$ Thucydides might easily have told the whole story of the siege of Syracuse in just a few words, but no direct account 'could have had a chance of equalling the animated and affecting description he has given of that memorable event.' $(L R B L, 86)$

Clearly, the strength of the indirect technique is that it allows the historian to register an emotional closeness to his story that in the earlier passage Smith seemed willing to allow only to the orator. The difference, of course, is that the orator (who is'nearly concerned' in events) can express himself in his own person. The historian, on the other hand, keeping to his stance of detachment, expresses his sentiments through appropriate surrogates. In this way he avoids violating the decorum of history and is rewarded for his fidelity to narrative by what may be an even more powerful tool for exciting the sentiments of his readers. I do not have time here to detail all the ramifications of this analysis, nor to show its relevance to an age when historical writing was increasingly seeking to go beyond the description of public action in order to evoke the textures of social life. For present purposes, however, it is important to point out that the subjective and proximative effects permitted by indirect description figure very largely in all Smith's judgments about historical writing. Again and again, Smith points to the evocative power of his favorite ancient historians - especially Livy, Thucydides, and Tacitus. Reciprocally, it is the lack of this capacity for 'animated and affecting description' that, in his mind, marks the weakness of the moderns. Indeed, an important part of his case against the philosophical 
and learned digressions favored by modern historians is the fact that these digressions interrupt the narrative and detract from its emotional impact. 'The historian who brings in long reflections ... withdraws us from the most interesting part of the narration.' $(L R B L, 103)$

\section{Kames's Elements of Criticism}

Lord Kames was a less inventive commentator on historical writing than Smith, but in some ways his work shows even more plainly the great importance that the writers of this period gave to effects of sentimental proximity. When we think of Lord Kames as an historical thinker, we generally have in mind the conjecturalist program of the Sketches of the History of Man. When we turn to Kames's Elements of Criticism (1762), however, we find a very different emphasis. ${ }^{7}$ Here the central issue is not the progress of mankind, but the moral psychology of the reader. Kames's argument, in essence, is that literary representation has the same power to stir the passions as actual experience, but only if the scene represented carries with it a high degree of vividness. This vivacity results in a loss of critical distance, converting the reader's experience into a kind of 'waking dream.' Kames calls this crucial effect 'ideal presence' and he claims for it a profoundly important role in the moral education of humankind. Though literary representation will always have an impact that is weaker than the force of experience itself, 'ideal presence' allows the lessons of experience to be prepared for or repeated in ways that account for 'that extensive influence which language hath over the heart. ${ }^{8}$

Ideal presence, as the name implies, is an aesthetic principle whose specific concern is the abbreviation of distance. In practice, much of Kames's critical writing amounts to reiterated injunctions to make description as actual and vivid as possible. 'Writers of genius,' he says, 'sensible that the eye is the best avenue to the heart, represent every thing as passing in our sight; and from readers or hearers, transform us, as it were, into spectators: ... in a word every thing becomes dramatic as much as possible.' (Elements, 3:174) Plutarch, he adds, observes that

7 The difference, it seems useful to underline, cannot be attributed to a radical change of mind, since Sketches contains many references to the earlier work. Rather, the contrast seems to be a matter of the different focus assumed in a work of belles-lettres.

8 [Kames] Elements of Criticism (Edinburgh, 1762) I:121. 
Thucydides 'makes his reader a spectator, and inspires him with the same passions as if he were an eye-witness.' Similarly, in another place he writes: 'The force of language consists in raising complete images; which have the effect to transport the reader as by magic into the very place and time of the important action, and to convert him as it were into a spectator, beholding every thing that passes.' (Elements, 3:174)

Ineed hardly say how significant the notion of transporting the reader into 'the very place and time' of the event would become, not only for historical narrative itself, but also for a whole family of associated genres, including the historical novel, biography, and history painting. The phrase carries with it, in fact, a strong sense of the transformation of historical distance that becomes pervasive in the early part of the next century. But Kames is not singling out historical evocation as such, though - as the reference to Plutarch's judgment on Thucydides shows - history is certainly one among many literatures that demonstrate the truth of his central principle. 'Upon examination,' he writes, 'it will be found, that genuine history commands our passions by means of ideal presence solely; and therefore that with respect to this effect, genuine history stands upon the same footing with fable. To me it appears clear, that our sympathy must vanish so soon as we begin to reflect upon the incidents related in either.' If we think that a story is nothing but fiction, he continues, the effect will be dissipated, but the same is true if we reflect that the persons described are no longer alive. 'It is present distress only that moves my pity. ${ }^{\prime 9}$ (Elements, 1:115)

\section{Hume's History of England}

Hume's writings on history exhibit the same tensions we have discovered elsewhere, but since Hume was not only a philosopher and an essayist, but also an important historian, he offers us the chance to look at the way in which the question of distance was negotiated in practice.

Historians have long regarded Hume's work as a history strongly marked by irony. This assessment is largely a response to Hume's authorial voice, whose tone is often heavily ironic, especially when commenting on the follies of religious and political enthusiasts. More

9 Note the parallels between Kames's views and those of Fontenelle, but where Kames wishes to discourage any kind of reflection that might interrupt the sense of immediacy, Fontenelle sees the consciousness of fiction as a necessary and useful attenuation of the impact of tragedy. 
recently, however, students of English literature, who tend to be less literal minded in their reading of texts, have looked at aspects of Hume's literary practice and found some highly wrought scenes of virtue in distress. ${ }^{10}$ Hume's staging of the death of Mary Queen of Scots, for example, or his picture of the last days of Charles I, far from being ironic, are clearly a product of eighteenth-century sentimentalism.

In short, we have been given two very different views of Hume's narratorial stance, with little sense of the need to reconcile the two or to coordinate both with other aspects of Hume's politics and aesthetics. In my view, irony and sentiment should be seen as two of the principal dimensions of historical distance in the History of England. Neither can really be understood in isolation, nor should the interplay of both be separated from other strategies by which Hume manipulates the sense of time, making us feel either more or less connected to the events under review. His 'philosophical' manner in dealing with the habits and customs of an earlier day, to take an obvious example, has the effect of increasing the separation between the then and the now; on the other hand, Hume will often quote letters, speeches, or other primary sources not so much for the information they contain as for the emotions they exhibit. These balances and tensions make up our experience of reading the History.

When we look more closely at the ironic and sentimental strands in Hume's narrative, we see that they are not, in fact, as far apart as we generally think. Many of Hume's most sentimental moments involve not only innocent sufferers but also their tormentors, who are the same religious and political bigots that provoke his irony. Thus the evident sentimentalism of the scene of the execution of Mary Queen of Scots, for example, is intensified by the brutality of the behavior of the Bishop of Peterborough, who continually harasses her to abandon her Catholic faith. The sentimental nature of this passage has everything to do with the fact that the spotlight is on the suffering woman; turn our attention to her clerical tormentor and the same scene would be transformed by ironic distance. ${ }^{11}$

10 On Hume's literary sentimentalism, see J. C. Hilson, 'Hume: The Historian as Man of Feeling,' in Augustan Worlds: Essays in Honour of A. R. Humphreys, eds. Hilson, Jones, and Watson (Leicester: Leicester UP, 1978). For a fuller account than I can give here of this dimension of Hume's historical writing, see my Society and Sentiment, chapters 1 and 2.

11 Hume, History of England (Indianapolis: Liberty P, 1983) 4:247-51. 
But it is not in the individual scene or event that we can truly see the full extent to which Hume's irony and his sentimentalism are interrelated; as his comments on Clarendon implied, there is a deeper level on which Hume recognized that the pleasures of historical sympathy were available only because of an ideological distantiation that (in part) manifests itself as irony. Ultimately the lesson of Hume's narrative of the seventeenth century is that Hanoverian Britain could look back on the Revolution as a phase of history now properly over, its tragic and pathetic scenes no longer to be confined by the partisan debates of earlier generations of historians and politicians. It was only because this comparative detachment had finally been achieved (so Hume believed, though his critics made him wonder) that it was possible to move beyond the pained reticence of Clarendon's generation to the sympathies of his own; only in this politically distanciated perspective could a murdered king be represented as a suffering father and a loving husband.

\section{The Reception of Hume's History in the Nineteenth Century}

Let me now turn very briefly to the issue of Hume's reception in the early part of the next century. In 'My Own Life,' Hume recalls the first appearance of his work and claims that Britons of every religious and political stripe were united 'in their rage against the man, who had presumed to shed a generous tear for the fate of Charles I and the Earl of Strafford..$^{12}$ The picture Hume paints is, of course, exaggeratedly negative. Nonetheless, it stands as a useful reminder that political and religious partisanship played a central role in response to Hume's work in this early phase. Nor did the political critique disappear in the nineteenth century; in fact, it reached a culmination in George Brodie's History of the British Empire, published in 1822, and it remained an element in the reception of Macaulay's history. Gradually, however, a different sort of discontent comes into view, one which paints Hume's history as intellectually abstract and emotionally thin. This second phase of criticism holds the work up to new criteria of judgment and it embraces all of Enlightenment historiography in its condemnation.

12 Hume's reference is the appearence of the first volume, that on the Stuarts, but he does not admit much of an improvement when subsequent volumes appeared. 
The first articulation of this criticism that I know of comes from James Mackintosh, himself an aspiring historian and one who held Hume in the highest esteem. In 1811, Mackintosh wrote in his journals: 'No other narrative seems to unite, in the same degree, the two qualities of being instructive and affecting. No historian approached him in the union of the talent of painting pathetic scenes with that of exhibiting comprehensive views of human affairs. ${ }^{13}$ Mackintosh's appreciation stands as a nice summary of just that tension this paper has tried to explicate, but along with his praises he also offered a criticism that would be prophetic for the growing reaction against the historical outlook of the Enlightenment. In Mackintosh's view, Hume's skeptical and rationalist temper seemed a limitation on his capacity for historical sympathy. Too often, he thought, Hume used his intelligence in the place of evidence. He 'was too habitually a speculator and too little of an antiquary, to have a great power of throwing back his mind into former ages, and of clothing his persons and events in their moral dress; his personages are too modern and argumentative - if we must not say too rational. ${ }^{14}$

Despite Hume's failures of sympathy, Mackintosh still judged him the greatest of historians. Two decades later, however, John Stuart Mill wondered whether Hume, Robertson, and Gibbon, for all their talents, should really be considered historians at all. Their histories, he charged, were populated by 'mere shadows and dim abstractions' whom no reader would recognize as 'beings of his own flesh and blood.' 'Does Hume throw his own mind into the mind of an Anglo-Saxon, or an Anglo-Norman?' Mill asks; does any reader feel he has gained 'anything like a picture of what may actually have been passing, in the minds, say, of cavaliers or of Roundheads during the civil wars? ${ }^{15}$

Carlyle, Macaulay, and a variety of others made much the same point, urging on historians the task of retrieving a quality of immediacy that, depending on the occasion, they identified with the freshness of primary documents, the vividness of Herodotus, or the fictional imagination of

13 Memoirs of the Life and Writings of Sir James Mackintosh, ed. R. Mackintosh, 2 vols. (Boston, 1853) 2:168. Mackintosh's manuscript journals, held in the British Library, are a rich source of comment on his literary and historical reading, as well as on private and official life.

14 Mackintosh, Memoirs, 2:169.

15 Mill, Essays on French History and Historians, ed. J. H. Robson and J. C. Cairns, (Toronto: U of Toronto P, 1985) 135. 
Walter Scott. ${ }^{16}$ None of these critics, it is clear, thought that in repudiating the qualities of aloofness and abstraction they identified with their Enlightenment predecessors, they might actually be following in the footsteps of Hume and Smith themselves.

\section{From Enlightenment to Romanticism: A Shift in Cognitive Distance}

In my earlier study of the historiography of the eighteenth century, I argued that the sentimental elements in Enlightenment histories revealed a much greater continuity between the writings of the eighteenth century and those of their successors than is usually acknowledged. I still hold this to be true, but to conclude this essay I want to refine this point using the clearer notion of distance developed earlier in this paper.

In retrospect, it seems clear that Romanticism did not produce as radical a redirection of historical thought as it seemed to those who created it. Indeed, our image of the historical sensibility of the Enlightenment as wholly abstract and detached is in many ways a myth created by the romantics as a foil for their own critique. For this reason, I have tried to show that alongside of the 'philosophical' dimension of Enlightenment historiography which has received so much attention there was also a very important sentimentalist influence which focused on the aesthetic attractions and moral training that result from soliciting the reader's sympathy. In the larger picture, then, we need to balance these two aspects of eighteenth-century historiography, keeping in mind that this period combined a view of historical knowledge that emphasizes generality with a view of narrative that stresses the aesthetic and ethical value of immediacy.

16 The romantic period is rife with statements that indicate the desire for a new sense of proximity in historical writing. Macaulay, for example, makes reiterated use of images of abbreviated distance to describe his ambition for a new, more imaginatively constructed historical understanding: 'To make the past present, to bring the distant near, to place us in the society of a great man or on the eminence which overlooks the field of a mighty battle, to invest with the reality of human flesh and blood beings whom we are too much inclined to consider as personified qualities in an allegory, to call up our ancestors before us with all their peculiarities of language, manner, and garb, to show us over their houses, to seat us at their tables, to rummage their old fashioned wardrobes ...' See 'Hallam,' in Critical and Historical Essays, ed J. A. Grieve (London: Dent, nd) 1:1. 
When the problem of continuity is stated in this way, some elements of discontinuity also stand out more clearly. The romantics, it is evident, not only deepened the desire for immediacy in areas in which sentimentalism had already prepared the way, but they also brought a new demand for proximity or engagement in places where eighteenth-century historical thought valued a greater degree of distantiation. From this point of view, the stylistic changes that we normally identify with romantic historiography, if taken in isolation, seem less innovative, since the desire to heighten the dramatic qualities of narrative can be seen as carrying further a longer standing movement towards actuality and immediacy. On the other hand, the shift to a new sense of proximity or engagement on both ideological and cognitive grounds has fewer precedents in the eighteenth century, and therefore probably contributes more fundamentally to the sense we have of encountering a new historical sensibility.

As I indicated earlier, Kames, Smith, and other eighteenth-century theorists of rhetoric and belles-lettres had also concerned themselves with ways to make narrative more distinct and believable. Their stress on the dramatic potential of historical narrative and their efforts to explore the moral and psychological effects of immediacy provide an important link between eighteenth-century sentimentalism and nineteenth-century romanticism. But there is also a crucial difference to be observed. Both groups of writers were interested in ways to make history more vivid or dramatic, but for the eighteenth-century writers the discussion centered on the psychology of reading, not on the quality of knowing. Their program calls for strategies to involve the reader as closely as possible in the narrative, so that he would respond more like a witness than a detached observer. Consequently, in belletrist discussion attention to formal distance is tied to the desire to abridge affective distance for the reader, which in turn is regarded as key to the ethical value of historical reading. The historian's own relationship to the past, on the other hand, is not explicitly at issue and there is no suggestion that a parallel abridgement of distance would provide a clearer or deeper understanding of realities remote from his own.

In Smith and Kames, in other words, the abridging effects of sympathy belong to the setting of criticism and moral psychology, not that of historical method or explanation. When they wrote about historical narrative, after all, both men were writing in a tradition of belles-lettres. From within this sphere they reworked the traditional view that history teaches by presenting ideal examples of character and action, replacing it with a new sense that history might contribute to virtue by providing vicarious exercises for the moral imagination, especially by soliciting sympathy for virtue in distress. But it has to be recognized that these 
sentimentalist doctrines did not immediately move beyond the issue of ethical instruction nor change the ways in which Smith and Kames thought about problems of historical understanding.

This is what changes in the new century, in ways that begin to be seen in Mill's criticism of Hume's failure to 'throw his mind' into the situation of another time. Mill's attack on the Enlightenment expresses a view of historical knowledge that was central to important strands of nineteenthcentury thought and has continued to have enormous influence in shaping the views of the historical profession. The key feature of this way of thinking about history is the opposition it establishes between distance and insight. On this view, genuine historical understanding is identified with the ability to penetrate the opacity or remoteness of past experience through an act of imaginative insight. More superficial minds, it is suggested, might content themselves with factual knowledge or empty generalization. But when we want to understand the real experience of past times, neither external explanation nor abstract theorizing will do. Ultimately, it was thought, we need to cultivate special qualities of historical insight and try to see more directly into past experience.

This view of historical understanding - canonized in the work of Dilthey, Meinecke, and Collingwood - has done a great deal to shape subsequent thinking about the proper forms of historical writing. For the historians of the Enlightenment, who began with quite different ideas about historical distance, the continuing influence of these views has created a persistently hostile climate of reception, from whose presuppositions only now are we beginning to liberate both Hume and ourselves.

MARK SALBER PHILLIPS

University of British Columbia 